Музеј Војводине, Нови Сад

DOI 10.5937/kultura1859093H

УДК 323.113(=163.41)(439.5)"1918"

94(497.1)

прегледни рад

\title{
БAPALDAY BPEME
}

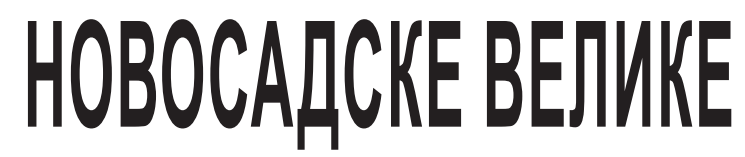

HAPOДНЕ СКУПШТИНЕИ

\author{
CTBAPAHA
}

JУГОСЛОВЕНСКЕ РРЖАВЕ

1918. ГOДИНЕ

Сажетак: Рад је посвећен кратком, али динамичном периоду у историји Барање и то у време стварањ прве југословенске државе. Када је реч о простору јужне Угарске (Банат, Бачка, Барања) преломни догађаји су кулминацију имали на новосадској Великој народној скупштини 25. новембра 1918. године, када је донета одлука да се ове територије отиепе од Аустро-Угарске Монархије и припоје Краљевини Србији, односно будућој југословенској држави. Циљ рада је да синтетички прикаже и објасни проиесе и догађаје у Барањи непосредно уочи и за време Велике народне скупштине у Новом Саду, закључно са Прводецембарским актом када је створена Краљевина Срба, Хрвата и Словенаиа. У писану су коришћене архивска грађа, оновремена штампа и публикаиије и релевантна историографска литература, како би наведени историјски период био што прецизније и свеобухватније анализиран.

Кључне речи: Барања, Први светски рат, јужна Угарска, стварање Југославије, новосадска Велика народна скупштина 
Избијање Првог светског рата поставило је пред политичко руководство Србије, не само проблем војне одбране, него и питање дефинисања ратних циљева и програма српске владе, који су требали бити реализовани након завршетка војних дејстава. ${ }^{1}$ „Нишком декларацијом”, коју је изгласала Народна скупштина Краљевине Србије 7. децембра 1914, ратни циљеви су сажети у следећој реченици: „Влада краљевине сматра као свој најглавнији и у овим судбоносним тренуцима једини задатак да обезбеди успешан свршетак овог великог војевања, које, у тренуцима, кад је започето, постало уједно борбом за ослобођење и уједињење све наше неслободне браће Срба, Хрвата и Словенаца". ${ }^{2}$ Скупштина је прихватила ову изјаву, која је саопштена и земљама Антанте ${ }^{3}$. Српска влада је „Нишком декларацијом” повезала борбу против Аустроугарске са југословенским уједињењем и разбијањем Двојне Монархије као државе. У том контексту, један део аустроугарских територија је требао постати део будуће југословенске државне заједнице укључујући и јужну Угарску, односно историјске области Банат, Бачку и Барању.

Током рата, српски интелектуалци су сарађивали с владом на конципирању граница будуће државе, образлажући историјским, географским, етнографским и другим аргументима поједине делове ратног програма. Барања је у ратним циљевима Србије посматрана заједно са Банатом и Бачком, као једна од војвођанских/јужноугарских области. Иако је знатно већи простор посвећен Бачкој и Банату, и Барању су поједини научници помињали у својим текстовима, у првом реду Јован Цвијић, Станоје Станојевић и Стојан Новаковић. Цвијић је 1915. године у књизи Јединство Југословена, која је представљала теоријско образложење „Нишке декларације“, географско-антрополошким агрументима означио границу будуће Југославије, укључивши целу Барању са градом Печујом у ,југословенски простор”. По његовом мишљењу, јужни део Панонске низије је до линије Мориш Суботица - Печујске планине (Мечек) - Мура представљао одвојену целину.

1 Текст је настао на основу истраживања за мастер-рад Барања у Краљевини Срба, Хрвата и Словенаца: 1918-1921, одбрањеног на Филозофском факултету у Новом Саду 2011. и затим делимично проширеног и објављеног под насловом Барања: 1918-1922, (2013) Нови Сад: Прометеј-Мало историјско друштво.

2 Šišić, F. (1920) Dokumenti o postanku Kraljevine Srba, Hrvata i Slovenaca 1914-1919, Zagreb: Matica Hrvatska, str. 10.

3 Митровић, А. У светском рату, у: Историја српског народа, књ. 6. Од Берлинског конгреса до уједињења: 1878-1918, том 2, ур. Митровић, А. и др. (1983) Београд: Српска књижевна задруга, стр. 66. 
Ипак, интелектуални и политички представници Србије нису имали јасне представе и прецизне податке о Барањи ${ }^{4}$, њеном географском опсегу, историји и становништву, што је нарочито дошло до изражаја на Конференцији мира у Паризу 1919-1920. За реализацију ратног програма српске владе од пресудног је значаја био распад Двојне Монархије. Догађаји који су уследили на крају Првог светског рата отворили су могућност да ратни циљеви српске владе буду реализовани, што је имало значајне последице и у случају Барање.

$* * *$

Коначна судбина територије јужне Угарске одређена је у сложеним и динамичним процесима који су се одвијали од средине септембра па до краја новембра 1918. године Прво су српска и савезничка војска пробиле Солунски фронт и у брзом напредовању до 19. октобра нашле се на граничним рекама између Србије и Аустроугарске. Тада је стање у Двојној Монархији већ увелико било хаотично. Владала је несташица животних намирница и социјални немири, а појавили су се и дезертерске одметничке групе из аустроугарске армије, „,огоши” и „зелени кадар”, што је доприносило општој несигурности.

Од највећег значаја за даљи равој догађаја у Банату, Бачкој и Барањи био је одговор америчког председника Вудроа Вилсона на аустроугарску ноту из октобра 1918, којом је тражен сепаратни мир на темељу Вилсонових „14 тачака” од 8. јануара исте године. Међутим, Вилсон је између осталог изјавио да се мир више не може склапати на основу његовог ранијег програма и ,да су народне тежње Југословена за слободом праведне. Стога [...] више не може признати пуку аутономију ових народа као основу за мир"5. Вилсон је на овај начин препустио југословенском становништву јужне Угарске да одлучи о својој судбини на основу права народа на самоопредељење. Распад Двојне Монархије је постао неминовност и већ крајем октобра 1918. године чехословачко народно веће у Прагу и Народно вијеће СХC у Загребу прогласили су отцепљење од Аустроугарске.

У Будимпешти је мађарска опозиција основала Мађарско народно веће, које је у својој Прокламацији захтевало завршетак рата, демократске, друштвене и привредне реформе

4 О томе више: Horvat, A. Baranja u ratnim ciljevima i teritorijalnim koncepcijama srpske vlade (1914-1918), u: Trijanon - dodiri i približavanja-znanstveni kolokvijum s međunarodnim sudjelovanjem, ur. Taslidžić, D. (2012) Beli Manastir: Društvo za baranjsku povjesnicu, str. 89-96.

5 Šišić, F. nav. delo, str. 179. 
и право народа на самоопредељење, али у оквиру територијалног интегритета Угарске ${ }^{6}$ У грађанско-демократској револуцији ,јесењих ружа" 31. октобра 1918. опозиција долази на власт и убрзо је створена Мађарска Демократска Република. Председник владе постао је вођа опозиције гроф Михаљ Карољи ${ }^{7}$. Мађарска влада је затим упутила проглас да се у свим местима формирају народна већа, која су требала преузети власт у своје руке и успоставити ред и мир. Социјални немири су у целој Угарској потрајали све до 10. новембра, када је дошло до извесног смиривања стања. Први дани новембра уједно представљају доминацију мађарских и немачких народних већа у Банату, Бачкој и Барањи ${ }^{8}$. У барањским градовима Мохачу и Печују основана су мађарска већа која су задржала власт у својим рукама и после уласка српске војске у Барању9.

У исто време, вођени су преговори између Мађарске и Антанте о условима примирја, који су отпочели 4. новембра у Београду између команданта савезничких трупа на Балкану Франшеа Депереа и команданта балканског фронта мађарског генерала Кевеша. Српска Врховна команда је тражила да Антантине трупе заузму територију „све до Мароша, Баје, Суботице и Печуја”. Гроф Карољи се укључио у преговоре 7. новембра, али договор није постигнут, јер он није хтео да прихвати тако широку окупациону зону и стране трупе у Суботици и Печују. Захтевао је да буде поштован интегритет Угарске. Међутим, Депере је наредио да се војне операције наставе ${ }^{10}$. На темељу наређења Депереа и војводе Живојина Мишића, српска војска је почетком новембра 1918. године прешла граничне реке и почела заузимати области преко Дунава и Саве ${ }^{11}$. Трупе српске I армије добиле

6 Месарош, Ш. Однос између мађарских народних већа и српских народних одбора у првој половини новембра 1918. године, у: Присаједињење Војводине Краљевини Србији 1918, уредник Смиљанић, М. (1993) Нови Сад: Музеј Војводине: Институт за историју Филозофског факултета, стр. 197.

7 Vinaver, V. (1971) Jugoslavija i Mađarska 1918-1933, Beograd: Institut za savremenu istoriju, str. 17-18.

8 Месарош, Ш. нав. дело, стр. 198-200. Карољијева влада је подстицала оснивање народних већа појединих народности у јужној Угарској, да би се успоставио ред и мир. Ова народна већа (одбори) нису се изјашњавали у корист интегритета Угарске, него у корист својих националноослободилачких тежњи.

9 Baranjski glasnik, 5. septembra 1920, br. 40.

10 Janković, D. i Krizman, B. (1964) Građa o stvaranju jugoslovenske države 1918, II, Beograd: Institut društvenih nauka, Odeljenje za istorijske nauke, str. 517-518

11 Његован, Д. (1993) Присаједињење Срема, Баната, Бачке и Барање Србији 1918. Документи и прилози, Нови Сад: Музеј Војводине, стр. 16-18. 
су 8. новембра наређење о граничним линијама. У Барањи, војска је требало да пређе Драву и да заузме целу област укључујући град Печуј. ${ }^{12}$

Ипак, војна конвенција о примирју коначно је потписана 13. новембра 1918. у Београду. Према њеним одредбама, мађарске трупе су морале евакуисати област северно од Мароша, Суботице, Баје и Печуја. Конвенција се није односила на политичка питања, па је њеном одредбом загарантовано да ће у јужној Угарској остати мађарска цивилна управа. Српска војска је тако војнички окупирала територије Баната, Бачке и Барање ${ }^{13}$. Београдска конвенција ипак није имала пресудан значај, јер су српске трупе и пре потписивања овог документа прешле граничне реке и стигле у Суботицу и Осијек, а одредба о мађарској администрацији није била одржива, па је врло брзо и прекршена.

Паралелно са овим догађајима, постепено се одвијао процес политичког организовања Срба, Буњеваца и других словенских заједница у јужној Угарској. Током октобра 1918. дошло је до неколико састанака у Суботици и Новом Саду на којима је расправљана будућа судбина Баната, Бачке и Барање. Крајем месеца, активирали су се и представници војвођанске Радикалне странке Јаше Томића. На тајном састанку у Суботици, који је организовао управо радикалски првак Јаша Томић, планирано је оснивање народних одбора у Новом Саду и целој Војводини и покретање српског листа. На састанку су учествовали и представници Барање ${ }^{14}$, али њихова имена нису позната. Вероватно је реч о неком од православних свештеника, који су били чланови Радикалне странке: брањински прота Стеван Михалџић, свештеник из Јагодњака Милутин Петровић или беломанастирски свештеник Светозар Панић.

И пре доласка српских трупа, почело је формирање српских народних одбора у Бачкој и Банату ${ }^{15}$. Централни Српски народни одбор ${ }^{16}(\mathrm{CHO})$ званично је основан у Новом Саду

12 Janković, D. i Krizman B. nav. delo, str. 517-518.

13 Vinaver, V. nav. delo, str. 21.

14 Храбак, Б. Словени у Војводини у данима ослобођења новембра 1918 , у: Присаједињење Војводине Краљевини Србији 1918, уредник Смиљанић, М. (1993) Нови Сад: Музеј Војводине: Институт за историју Филозофског факултета, стр. 67.

15 Први српски народни одбор је основан у Великом Бечкереку 31. октобра 1918.

16 У току новембра у Нови Сад је из Загреба дошао млади Барањац Милан Кашанин и ставио се на располагање Српском народном одбору. Радио је као новинар у „Српском листу”, новинама СНО-а Накнадно је примљен у Српски народни одбор као члан. Осим Кашанина, у одбор је 
3. новембра 1918. године. У раду СНО учествовале су све српске политичке странке. Одбор је требао бити проширен и са политичким представницима осталих Словена јужне Угарске ${ }^{17}$. Исти дан је објављен проглас у којем је стајало „да сваки народ има права сам одређивати својом судбином"18. У одговору на покушај Карољијеве владе да поједине општине изјаве поверење влади у Будимпешти, СНО је позвао „све општине Бачке, Баната и Барање, да се у погледу политичког држања свог имају покоравати једино наредбама и упутствима Српског народног одбора у Новом Саду, као централног представника Бачке, Баната и Барање, који сазива Велику Народну Скупштину Срба, Буњеваца и осталих Словена, да се у име целокупног народа ових крајева слободно определи"19. Задатак СНО је био да успостави ред и мир, а после уласка српске војске у Нови Сад 9. новембра ${ }^{20}$, могао се у потпуности посветити политичком задатку припреме Велике народне скупштине, која је требало да прогласи одвајање од Угарске и одреди начин уласка Баната, Бачке и Барање у будућу југословенску државу ${ }^{21}$.

По том питању, међу политичким представницима јужноугарских Срба постојале су две концепције. С једне стране, група предратних либерала и демократа окупљена око секретара Матице српске Тихомира Остојића предлагала је да се уједињење оствари преко Народног вијећа у Загребу, које је претендовало да представља све бивше аустроугарске области насељене југословенским становништвом. С друге стране, Јаша Томић и његова Радикална странка су захтевали да се Банат, Бачка и Барања прво припоје Краљевини Србији, а затим уђу у јединствену државу. Томићева опција је на Великој народној скупштини однела превагу иако су постојале оштре дискусије све до одржавања саме Скупштине.

ушао још један Барањац: Светозар Страјнић, као градски представник Новог Сада; Попов, Д. (1983) Српска штампа у Војводини 1918-1941, Нови Сад: Матица српска, стр. 20; Његован Д. (1993) Присаједињење Срема, Баната, Бачке и Барање Србији 1918. године. Документи и прилози, Нови Сад: Музеј Војводине, стр. 71-72).

17 Његован, Д. (2004) Присаједињење Војводине Србији. Прилог политичкој историји Срба у Војводини до 1921. године, Нови Сад: Музеј Војводине, стр. 223-224.

18 Његован, Д. Присаједињење - Документи и прилози, стр. 19.

19 Исто, стр. 21.

20 До 21. новембра заузета је цела територија до демаркационе линије, одређене Београдском конвенцијом.

21 Кркљуш, љ. Војводина у време присаједињења Краљевини Србији 1918. године, у: Присаједињење Војводине Краљевини Србији 1918, уредник Смиљанић, М. (1993) Нови Сад: Музеј Војводине: Институт за историју Филозофског факултета, стр. 18. 
У исто време док су трајали политички договори и припреме Велике народне скупштине, српска војска је постепено стављала под војну контролу простор јужне Угарске. Након заузимања Новог Сада и Бачке, један део трупа Дринске дивизије је кренуо према Осијеку, који је заузет 12. новембра ${ }^{22}$. На основу Београдског примирја, српска војска је 14. новембра 1918. прешла Драву код Осијека и ушла у Барању². Два дана раније у Осијек је дошао Бошко Михалџић, син брањинског проте, доносећи молбу „свих српских села” да војска пређе Драву и уђе у Барању. Молбу је предао пуковнику Ђоки Ђорђевићу ${ }^{24}$. Ипак, ова манифестација народне воље није била пресудна за покретање српске војске преко Драве, него ратни циљеви Србије дефинисани у току рата, наређења Франша Депереа и војводе Мишића и већ поменута конвенција потписана у Београду, која је званично одредила демаркациону линију.

Војску је пратио члан осјечког Народног вијећа, учитељ Милан Глибоњски. Као добар познавалац барањских прилика, знао је податке о распореду насеља и становништву. ${ }^{25}$ Војна команда је одлучила да пошаље Глибоњског да извиди стање у Барањи и установи у каквом је стању пруга према Печују, јер је одлучено да транспорт војске буде извршен железницом. Глибоњски се у Дарди повезао са православним свештеницима, обавестио их о доласку српске војске, а обавештење је прослеђено и Тодору Андрићу у Мохач, угледном српском адвокату и посланику у угарском сабору ${ }^{26}$.

Након што је српска команда у Осијеку добила обавештења од Глибоњског, трупе Дринске дивизије кренуле су у Барању, а напредовале су у три правца: према линији Дарда - Вилањ

22 Pekić, P. (1939) Povijest oslobođenja Vojvodine, Subotica: s. n., str. 259.

23 Na dan oslobođenja, Baranjski glasnik, 14. novembra 192, str. 50. У литератури је хронологија уласка српске војске у Барању непрецизна и неодређена. Ј. Безендорфер у свом раду „Нешто мало о нашој Барањи” наводи 13. новембар 1918. године. Истим податком барата и Петар Пекић у раду „Повијест ослобођења Војводине”, па је Безендорфер вероватно од њега преузео тај податак. Глибоњски је још непрецизнији и пише да је прелазак преко Драве био крајем октобра. Михалџић, иначе прецизан у хронологији, у својим радовима наводи 14. новембар. Београдска „Политика” од 17. новембра 1919. у чланку „Част Србији” (Печуј, 14. новембар) преноси чланак „Пре годину дана”, објављен у „Барањском Гласнику”, а који „слави годишњицу ослобођења“.

24 Михалџић, С. Барања - ослобођена, у: Споменииа ослобођења Војводине: 1918, (1929) Нови Сад: Штампарија Јовановић и Богданов, стр. 83.

25 Глибоњски, М. (2009) Барања (1918-1923) сећања, пр. Крестић, В. Београд: Историјски институт, стр. 12-13.

26 Исто, стр. 13. 
- Шиклош - Печуј, према Барчу на Драви и према Мохачу и Батосеку на Дунаву. Коњица је железницом пребачена у Мохач, где је војска била изненађена „ванредно лепим дочеком”, који је организовао Тодор Андрић ${ }^{27}$. До 17. новембра трупе су заузеле Дарду, Бели Манастир, железничку пругу Осијек-Печуј и Вилањ-Мохач и скелу на Дунаву у Батини, Печуј $^{28}$ и територију до Барча и Сигетвара. Српска војска у Барањи је две недеље после добила наређење Прве армије, са коначном демаркационом линијом према Мађарској: „Полазила је до моста на Драви код Барча, затим описивала Сигет и Печуј, избијала на Чико, па испод манастира Грабовца, до Батосека да би изнад њега избила и прешла Дунав на Душнок-Сикошу"29. Ипак, није се цела Барањска жупанија нашла под контролом српске војске, него срезови: брњеварски (дарђански), мохачки и шиклошки, већи део печујског и печварског среза и неколико села шашког (хеђкатског) среза. Изван граница демаркационе линије остао је скоро цео шељински (св. Лорински) сре $3^{30}$.

Српско становништво Барање дочекало је српске трупе са одушевљењем ${ }^{31}$. Слична атмосфера је владала и у шокачким (хрватским) селима уз Карашицу и у околини Печуја ${ }^{32}$. О статусу који је српска војска уживала међу становништвом, брањински прота Стеван Михалџић је забележио следеће: „У Печују стекла је наша војска већ при самом уласку највеће поштовање. Њезино симпатично поступање према свакоме [...] створила јој је... такву љубав свега народа, да се ... слободно могла кретати по свима најмађарскијим местима и крајевима без икакве веће опрезности. Ово поштовање према нашој војсци очувало се и доцније"з3. У мемоарима М. Глибоњски пише да је мађарско становништво „обрадовало

\section{7 Исто.}

28 Михалџић, С. (1992) Барања од најстаријих времена до данас, Београд: Библиотека града Београда, стр. 405.

29 Павловић, Р. О Тријанонском уговору и о првим исељавањима Срба из Мађарске 1921. године, у: Патријарх српски Арсеније III Чарнојевић и Велика сеоба Срба 1690. године: зборник радова о тристагодишьиuуи Велике Сеобе, ур. епископ шумадијски Сава, (1997) Београд: Свети архијерејски синод Српске православне цркве, стр. 197.

30 Baranjski glasnik, 13. marta 1921, br. 67.

31 О атмосфери међу барањским Србима, Михалџић у делу „Барања-ослобођена”, пише следеће: „Јуначки продор српске војске код Кајмакчалана испунио је српска срца у Барањи позитивном надом...Кајмакчалан (je) коначно решио загонетку двоједне монархије! Заман се позивало, да се заснују мађарски национални одбори и мађарска народна одбрана. У српским опћинама у Барањи запуцале су пушке, па још државне, у одбрану српске мисли и српских нада".

32 Pekić, P. nav. delo, str. 260.

33 Михалџић, С. Барања-ослобођена..., стр. 83. 
и развеселило држање српских војника који су им дошли и понашали се као пријатељи" "34. Држању српске војске су допринела и наређења команде Дринске дивизије, којима је прописан строги прогон војника који би пљачкали, бахато се односили или светили несловенском становништву. О коректном понашању српске војске сведочи и изјава Карољија из децембра 1919. године да су „мађарска популација, а и сама влада, задовољни држањем (српске) војске, док су Румуни и Чеси разуздани и само пљачкају”. У току децембра завршено је размештање српских трупа у Барањи, формирана је Барањска посада, а за команданта је постављен пуковник Војин Чолак-Антић ${ }^{35}$.

Приближно у исто време, 17. новембра 1918, СНО у Новом Саду је упутио изборни ред за Велику народну скупштину свим народним одборима у Војводини. Према изборном реду Срби, Буњевци и остали Словени су бирали делегате по општинама, тако да 1.000 становника бира једног представника. У општинама мањим од 200 становника, становници бирају посланика у суседној најближој општини. Општине између 200 и 1.000 становника бирају једног делегата. За посланике су могли бити изабрани и чланови других општина. Право гласа су имали сви мушкарци и жене старији од 20 година. У општинама где још нису били формирани народни одбори, требало их је одмах формирати ${ }^{36}$. Према изборном реду право гласа нису имали Мађари, Немци и Румуни ${ }^{37}$.

Пре доласка српске војске, у Барањи нису постојали српски и шокачки (хрватски) народни одбори. Средином новембра одржано је неколико састанака у Дарди и Белом Манастиру на којима је договорен начин политичког организовања словенског становништва ове области. Дана 21. новембра на црквеној слави у Белом Манастиру окупила се велика група људи да би се утврдила предстојећа акција и правци деловања. Присутан је био и пуковник Драгиша Костић, тада заповедник барањске посаде ${ }^{38}$. Политичко организовање српског становништва у своје руке преузели су православни свештеници, чланови Радикалне странке, Стеван Михалџић у Брањини, Светозар Панић у Белом Манастиру и Милутин

34 Глибоњски, М. нав. дело, стр. 14.

35 Павловић, Р. нав. дело, стр. 197-198.

36 Његован, Д. Присаједињење - Документи и прилози..., стр. 32-33.

37 Ова три народа су чинила скоро 56 \% тадашњег становништва Баната, Бачке и Барање, према попису из 1921 , а право гласа им је одузето због предвиђене могућности оптације за њихове националне државе. Исти принцип је задржан приликом избора за Уставотворну скупштину Краљевине СХС 1920. године.

38 Михалџић, С. Барања-ослобођена.., стр 84. 
Петровић у Јагодњаку. Веза са СНО у Новом Саду ишла је преко Сомбора, односно Поповца, одакле су вести ширене по осталим местима у Барањи, а тим путем је стигао и позив за Велику народну скупштину у Новом Саду ${ }^{39}$.

Избори барањских представника за скупштину у Новом Саду одржани су од 21. до 24. новембра 1918. године. У складу са одредбама изборног реда, за делегате су бирани најугледнији људи у појединим општинама. Избори у Болману су одржани 21. новембра, уз учешће око 300 људи. Прво се приступило формирању народног одбора, затим избору председника, потпредседника и осталих одборника. За председника је изабран Мирко Бојанин, за потпредседника Сава Доброкес, а за секретара Станоје Бојанин. Одбор је имао 16 чланова. Председник је на дневни ред ставио питање да ли ће се Српском народном одбору у Новом Саду признати да је „позван говорити у име свег нашег народа у Угарској”. Након што је једногласно усвојен овај предлог, Мирко Бојанин је такође једногласно изабран за болманског представника у новосадској Великој народној скупштини ${ }^{40}$.

Истог дана је одржана скупштина у Барањском Бану (Поповцу). Председник народног одбора био је православни свештеник Дионисије Мијатовић ${ }^{41}$. За делегате су изабрани Стокан Урсић, Симо Дворнић, Стокан Мајшац, Стево Дворнић, Саво Миодраговић и Роман Станковић ${ }^{42}$. Записник са изборне скупштине није сачуван, али можемо претпоставити да су представници шокачких општина уз Карашицу учествавали у изборима, јер Поповац није имао толики број становника да би могао бирати 6 посланика.

Избор представника у Пелмоноштору (Белом Манастиру) одиграо се два дана касније. Према записнику са изборне скупштине $\mathrm{4}^{43}$, Бели Манастир је тада имао 420 „српских

39 Исто, стр. 83.

40 Записник скупштине са седнице целокупног српског народа у Болману, Рукописно одељење Матице српске, инв. бр. М 7.417. Записник су потписали председник одбора, секртетар и учитељица Марија Михајловић.

41 Веровница Симе Дворнића, РОМС, М 7.417.

42 Његован, Д. Присаједињење - Документи и прилози..., стр. 107.

43 У Рукописном одељењу Матице српске сачувани су записници са изборних скупштина Болмана, Белог Манастира, Дарде и Мохача и пуномоћи посланика из наведених места, Поповца, Брањине и Јагодњака. Записници нису оригинални документи, него оверени преписи, које су поједини посланици морали доставити СНО-у у Новом Саду као доказ уз пуномоћ, а писани су ћирилицом. Оверени су печатима православних црквених општина. Записнике су потписивали председник одбора и перовођа (тајник, секретар). У записницима су према упутствима изборног реда СНО-а, забележени дан и место избора, имена изборних часника, број становника у појединим местима, ток гласања и имена 
душа", а заједно са околним местима Сударашем, Брњеваром и Брајдфелдом 540. Председник народног одбора био је православни свештеник Светозар Панић, потпредседник Стеван Чарнојевић, а секретар Милан Прерадовић. Народни одбор је имао 11 чланова. Председник одбора је присутним „одборницима и изборницима” предложио Стевана Чарнојевића за пелмоношторског посланика, што је акламацијом, једногласно прихваћено ${ }^{44}$.

У Дарди је избор делегата одржан истог дана као у Пелмоноштору. Према извештају парохије, Срба у Дарди је било 980..$^{45}$ Председник одбора био је Душан Милутиновић, потпредседник Милан Јовановић, а секретар Светозар Панић. Одбор је имао 11 чланова. Милутиновић је пре почетка гласања саветовао да се избор посланика обави једногласно како би се „што јаче манифестовала једнодушност дарђанских Срба". У том духу, једногласно и акламацијом изабран је Теодор Чварковић ${ }^{46}$.

У исто време одржан је избор посланика и у Качфали (Јагодњаку). Председник одбора био је свештеник Милутин Петровић, а секретар Војин Јовановић. За посланика је изабран Петровић ${ }^{47}$.

Дана 23. новембра одржан је и народни збор у Кишфалуби (Брањини). Председник одбора је био Ђоко Косић, а секретар Стеван Поповић. За посланике су изабрани прота Стеван Михалџић и Стеван Поповић ${ }^{48}$. Као и у случају Поповца, могуће је да су у изборима учествовали представници шокачких општина, јер Брањина није имала више од 1000 становника српске националности, па није могла да бира више од једног делегата.

Нека барањска места су пријавила организовање одбора директно СНО-у у Новом Саду. Одбор у Бремену је известио да је председник одбора Милан Костовић, а секретар Ђорђе Петровић. У Липови је председник одобора био Милутин Мирковић, а секретар Јован Ердељан. Одбор је имао 21

посланика. Сви посланици Барањци из наведених места су имали пуномоћи (веровнице, исказнице) којим су доказивали свој избор. Пуномоћи су такође потписивали председник одбора и секретар, и оверени су печатом црквене општине.

44 Препис записника вођеног при избору посланика за Пелмоноштор у Народну скупштину, РОМС, М 7.417.

45 Српско православно парохијско звање у Дарди, РОМС, М 7. 417.

46 Препис записника, вођеног при избору дарђанског посланика, РОМС, М 7.417 .

47 Пуномоћ Милутина Петровића, РОМС, М 7.417.

48 Исказница Стевана Михалиића, РОМС, М 7. 417. 
члана ${ }^{49}$. Председници и секретари ових одбора су изабрани за политичке представнике својих места ${ }^{50}$.

Милан Глибоњски је добио задатак од осјечког Народног вијећа да организује Србе и Шокце у Мохачу и околини. Ступио је у контакт са Тодором Андрићем и Томом Пракатуром, мохачким адвокатом, који је пореклом био Шокац из Дубошевице. Према плану Осјечког народног вијећа шокачке и српске оштине су требале донети појединачне резолуције о присаједињењу Барање Краљевини $\mathrm{CXC}^{51}$. Разлог за доношење појединачних резолуција био је у томе што није било времена да се пошаљу сви изабрани представници у Нови Сад. Глибоњски је Пракатру уручио писмо осјечког Народног вијећа, који је том приликом изјавио „да он јавно неће радити јер се боји освете Мађара, али ће у потаји све учинити"52. Срби у Мохачу су се ипак на брзину организовали. У оснивању народног одбора и изборима суделовао је и најугледнији мохачки Србин Тодор Андрић. Само дан уочи Велике народне скупштине у Новом Саду, одржани су избори за мохачког посланика. Према записнику са изборне скупштине, у Мохачу је живело 800 Срба. За председника одбора изабран је Давид Бркић, а за секретара Лазар Плавшић. За представника је једногласно изабран Јоцо Панић, ратар из Мохача ${ }^{53}$.

Своје посланике на Велику народну скупштину која је одржана у Новом Саду 25. новембра, послало је укупно 211 општина из Баната, Бачке и Барање. У изворима и литератури недостају имена 10 посланика и 7 општина. Установљено је да су све банатске општине послале посланике, а из Бачке није само једна. Према томе, осталих 6 су из Барање ${ }^{54}$, а вероватно су у питању шокачке општине из околине Печуја и(ли) околине Мохача. За сада нису пронађени изворни документи према којим би се са сигурношћу установило да ли су, и које су, шокачке општине послале посланике у Нови Сад.

49 Споменица ослобођења Војводине 1918, (1929) Нови Сад: Штампарија Јовановић и Богданов, стр. 80-81.

50 Његован, Д. Присаједињење - Документи и прилози..., стр. 106.

51 Bösendorfer, J. (1940) Nešto malo o našoj Baranji, Osijek: Prva hrvatska dionička tiskara, str. 35. Безендорфер пише да је „на интервенцију војних власти (мајор Јовановић) Пракатур 27. новембра у Мохачу основао шокачко народно вијеће, али се већ наредног дана (28. новембра) придружио мађарском народном вијећу".

52 Baranjski glasnik, 6. maja 1920, бр. 23.

53 Записник вођен у изборној скупштини Срба у Мохачу, РОМС, М 7.417.

54 Његован, Д. Присаједињење - Документи и прилози..., стр. 107. 
У односу на Банат и Бачку, за процес формирања народних одбора у Барањи је карактеристично неколико разлика, које су допринеле да рад на њиховом оснивању не буде тако успешан. У Барањи није било политичке организације, нити оснивања српских и шокачких народних одбора све док српска војска није заузела област. Главни узроци ове појаве су у етничком саставу становништва и друштвеној структури Срба и Шокаца. У Барањској жупанији је према попису становништва из 1910. године живело 350.000 становника, од тога мање од 7\% српског, хрватског и шокачког становништва, у односу на $56 \%$ Мађара и $32 \%$ Немаца. У погледу друштвене структуре, преовладавало је сељаштво, а интелектуална и политичка елита готово да нису ни постојале, као ни хомогенија страначка организација. Није постојала развијена политичка свест као у Бачкој и Банату, где је један део Срба, Шокаца и Буњеваца живео у градовима, био школован и бавио се политиком. У Барањи су градове претежно насељавали Мађари и Немци, а Срби и Шокци су били углавном сеоско становништво и мало их је живело у већим местима. При том, Шокци у Барањи су били без својих учитеља, новина, странака и политичких вођа. Важан узрок слабијој организацији је био и недовољан временски период, јер је Велика народна скупштина заказана за 25. новембар 1918. године.

Због наведених разлога, барањски делегати су били из места насељених српским становништвом, изузев како смо већ напоменули, вероватно Поповца и Брањине. Такође, и у географском погледу, осим Мохача, сви политички представници су били из тзв. Барањског троугла, односно простора јужне Барање где је уједно живео највећи део барањског становништва јужнословенског порекла. Према попису становништва из 1921, ту је живело 15.602 „Србо-Хрвата”, 16.638 Мађара и 15.976 Немаца ${ }^{55}$.

Михалџић је у „Споменици ослобођења Војводине 1918.“, писао да „су све наше српске и шокачке општине послале своје изасланике на ту Скупштину"56. Свакако да овај податак није тачан што се тиче шокачких општина, али као што смо већ напоменули, постоји могућност да су неке општине уз Карашицу и у околини Печуја и Мохача имале своје посланике у Новом Саду.

55 Ћурчић, С. и Кицошев, С. (1992) Развој популащије Барање, Бели Манастир: Народни универзитет Вук Караџић, Нови Сад: Музеј Војводине, Београд: Друштво Српска Крајина, стр. 46.

56 Михалџић, С. Барања-ослобођена..., стр. 83. 
Неразвијена политичка свест у Барањи доприносила је целокупној слици о необавештености барањског становништва о политичким околностима и територијалним претензијама српске владе дефинисаним у ратном програму и на крају у Београдској конвенцији. Срби у Барањи су већином страховали да не остану изван граница будуће југословенске државе, немајући информације да се Барања налазила у оквиру територијалног програма српске владе. С једне стране, српска влада није имала сасвим прецизне информације о Барањи и њеном становништву, а с друге стране Барањци нису имали обавештења о плановима српске владе.

$$
* * *
$$

Велика народна скуштина Срба, Буњеваца и осталих Словена у Банату, Бачкој и Барањи састала се у Новом Саду 25. новембра 1918. године. На Скупштини је учествовало 757 посланика из 211 општина: 578 Срба, 84 Буњевца, 3 Шокца, 2 Хрвата, 62 Словака, 21 Русин, 6 Немаца и 1 Мађар. Из Барање је по именима познато 17 посланика. Прота Михалџић тврди да их је било око 30, Срба и Шокаца ${ }^{57}$. Претпостављамо да је број од 10 посланика који недостају на пописима посланика такође из Барање, тако да би вероватан укупан број био 27 посланика Барањаца. Постоји могућност, као што је извесно био случај у Поповцу и Брањини, да су људи српске националности изабрани да представљају поједина шокачка места.

Прву одлуку у 4 тачке, коју је скупштина прихватила, прочитао је Јаша Томић. Одлучено је да на предстојећој мировној конференцији влада Србије заступа интересе Баната, Бачке и Барање. Затим да се Банат, Бачка и Барања прикључују Краљевини Србији, а све да би се помогло уједињење свих Срба, Хрвата и Словенаца. У 4. тачки одлуке стоји да ће скупштина послати по 2 члана у Загреб и Београд да би се југословенско уједињење што пре остварило. Прва одлука је допуњена изјавом о заштити несловенских мањина које ће остати унутар граница нове државе ${ }^{58}$.

Другу одлуку образложио је Петар Коњовић следећим речима: „Банат, Бачка и Барања у границама, које повуче Антантина балканска војска, проглашује се данас 12. (25) новембра 1918. године на Великој народној скупштини на основу узвишеног начела народног самоодређивања отцепљеном, како у државно-правном, тако и у политичком и привредном погледу од Угарске. Због тога Народна скупштина поставља

57 Исто, стр. 86.

58 Његован, Д. Присаједињење Војводине Србији.., стр. 241-242. 
Велики народни савет, којем је извршни орган Народна управа. Народни савет чине 50 чланова, изабрани из ове Народне скупштине. Народни савет доноси потребне уредбе и наредбе, поставља Народну управу и врши надзор над њом". Народну управу је чинило 11 одсека, а на челу сваког одсека стајао је Народни повереник. Значајан говор одржао је и Блашко Рајић у име Буњеваца и Шокаца, пристајући на договорене одлуке Скупштине ${ }^{59}$. Након што су скупштинске одлуке образложене и усвојене, изабран је Велики народни савет (ВНС). Од Барањаца, Михалџић је изабран за једног од чланова ВНС. Истог дана у званичном листу барањске жупаније и на плакатима на српском, мађарском и немачком језику изашла је прокламација српске војске „народу барањском", у којој се становништво позива да настави свој слободан и редован посао ${ }^{60}$.

Већ сутрадан, 26. новембра делегација Велике народне скупштине отпутовала је у Београд, предвођена Јашом Томићем и Блашком Рајићем. Делегација је имала задатак да упозна српску владу и регента Александра о скупштинским одлукама. Регент је примио делегацију у саставу: Ј. Томић, Б. Рајић, С. Михалџић, Славко Милетић и Душан Степанов. Испред делегације, први је говорио Стеван Михалџић, а „Српски лист” је поводом тога писао: „Престолонаследника је поздравио дивним и одушевљеним говором поп Михалџић из Барање, отац Воје Михалџића, правника, који је на српском фронту погинуо као добровољац српске војске. Ватреним речима протумачио је угледни свештеник осећаје Војвођана и њихову приврженост Србији и њеном краљевском дому"61. Друга делегација предвођена Васом Стајићем и Јованом Манојловићем кренула је у Загреб, са циљем што бржег стварања југословенске државе ${ }^{62}$.

Када је Прводецембарским актом створена Краљевина СХC, Барања се нашла у оквиру југословенске државе, али са отвореним питањем граница, која је требало бити утврђена на Конференцији мира у Паризу. Већ 3. децембра, Мађари у Барањи су организовали збор у Печују, протестујући против

59 Његован, Д. Присаједињење - Документи и прилози..., стр. 45. Одсеци у Народној управи су следећи: Политички послови, унутрашњи послови, правосуђе, посвета, финансије, саобраћај, привреда, прехрана и снабдевање, социјалне реформе, народно здравље, народна одбрана.

60 Михалџић, С. Барања-ослобођена..., стр. 84.

61 Његован, Д. Барањско питање 1914-1941, у: Дневник проте Стевана Михалуића, приредио Његован, Д. (2000) Нови Сад: Музеј Војводине; Београд: Београдско читалиште, стр. 155-156.

62 Pekić, P. (1930) Povijest Hrvata u Vojvodini od najstarijih vremena do 1929, Zagreb: Matica hrvatska, str. 185. 
одлука новосадске скупштине ${ }^{63}$. Међутим, убрзо је почела организација Народне управе и југословенксе администрације у Барањи, па одлуке овог збора нису уважене од стране нових власти.

Коначан статус Барање је разрешен на Конференцији мира у Паризу. Југословенско-мађарским разграничењем и Тријанонским споразумом из 1920. године, Краљевини СХC је припао тзв. Барањски троугао, територија површине 1147 $\mathrm{km}^{2}$ у јужном делу покрајине, док је већи део области са градовима Печујем и Мохачем остао саставни део Мађарске.

\section{ИЗВОРИ И ЛИТЕРАТУРА:}

Рукописно одељење Матице српске, Нови Сад, М 7. 417.

Baranjski glasnik, Pečuj (1919-1921).

Bösendorfer, J. (1940) Nešto malo o našoj Baranji, Osijek: Prva hrvatska dionička tiskara.

Vinaver, V. (1971) Jugoslavija i Mađarska 1918-1933, Beograd: Institut za savremenu istoriju.

Глибоњски, М. (2009) Барања (1918-1923) сећања, приредили Крестић, В. и Крестић, П, Београд: Историјски институт.

Janković, D. i Krizman, B. (1964) Građa o stvaranju jugoslovenske države 1918, II, Beograd: Institut društvenih nauka, Odeljenje za istorijske nauke.

Кркљуш, Љ. Војводина у време присаједињења Краљевини Србији 1918. године, у: Присаједињење Војводине Краљевини Србији 1918, уредник Смиљанић, М. (1993) Нови Сад: Музеј Војводине: Институт за историју Филозофског факултета, стр. 13-24.

Месарош, Ш. Однос између мађарских народних већа и српских народних одбора у првој половини новембра 1918. године, у: Присаједињење Војводине Краљевини Србији 1918, уредник Смиљанић, М. (1993) Нови Сад: Музеј Војводине: Институт за историју Филозофског факултета, стр. 197-202.

Митровић, А. У светском рату, у: Историја српског народа, књ. 6. Од Берлинског конгреса до уједињења: 1878-1918, том 2, (1983) Београд: Српска књижевна задруга.

Михалџић, С. Барања-ослобођена, у: Споменииа ослобођења Војводине: 1918, (1929) Нови Сад: Штампарија Јовановић и Богданов.

Михалџић, С. (1992) Бараға од најстаријих времена до данас, Београд: Библиотека града Београда.

63 Bösendorfer, J. nav. delo, str. 36. 


\section{АЛЕКСАНДАР ХОРВАТ}

Његован, Д. Барањско питање 1914-1941, у: Дневник проте Cтевана Михалиића, приредио Његован, Д. (2000) Нови Сад: Музеј Војводине; Београд: Београдско читалиште

Његован, Д. (1993) Присаједињење Срема, Баната, Бачке и Бараюе Србији 1918. Документи и прилози, Нови Сад: Музеј Војводине.

Његован, Д. (2004) Присаједињење Војводине Србији. Прилог политичкој историји Срба у Војводини до 1921. године, Нови Сад: Музеј Војводине.

Павловић, Р. О Тријанонском уговору и о првим исељавањима Срба из Мађарске 1921. године, у: Патријарх српски Арсеније III Чарнојевић и Велика сеоба Срба 1690. године: зборник радова о тристагодишғичи Велике Сеобе, ур. епископ шумадијски Сава, (1997) Београд: Свети архијерејски синод Српске православне цркве, стр. 197-208.

Pekić, P. (1939) Povijest oslobođenja Vojvodine, Subotica: s. n.

Pekić, P. (1930) Povijest Hrvata u Vojvodini od najstarijih vremena do 1929, Zagreb: Matica hrvatska.

Попов, Д. (1983) Српска штампа у Војводини 1918-1941, Нови Сад: Матица српска.

Споменииа ослобођења Војводине 1918, (1929) Нови Сад: Штампарија Јовановић и Богданов.

Ћурчић, С. и Кицошев, С. (1992) Развој популаиије Барање, Бели Манастир: Народни универзитет Вук Караџић, Нови Сад: Музеј Војводине, Београд: Друштво Српска Крајина.

Horvat, A. Baranja u ratnim ciljevima i teritorijalnim koncepcijama srpske vlade (1914-1918), u: Trijanon - dodiri i približavanja - znanstveni kolokvijum s međunarodnim sudjelovanjem, ur. Taslidžić, D. (2012), Beli Manastir: Društvo za baranjsku povjesnicu, str. 89-96.

Храбак, Б. Словени у Војводини у данима ослобођења новембра 1918, у: Присаједињење Војводине Краљевини Србији 1918, уредник Смиљанић, М. (1993) Нови Сад: Музеј Војводине: Институт за историју Филозофског факултета, стр. 59-74.

Šišić, F. (1920) Dokumenti o postanku Kraljevine Srba, Hrvata i Slovenaca 1914-1919, Zagreb: Matica Hrvatska. 


\title{
АЛЕКСАНДАР ХОРВАТ
}

\author{
Aleksandar Horvat \\ Museum of Vojvodina, Novi Sad

\section{BARANJA DURING THE GRAND NATIONAL ASSEMBLY IN NOVI SAD AND THE CREATION OF THE YUGOSLAV STATE IN 1918}

\begin{abstract}
This paper covers a brief but dynamic period in the history of Baranja, at the time of creation of the first Yugoslav state. When it comes to the area of southern Hungary (Banat, Bačka, Baranja), the crucial events took place in the Grand National Assembly on November 25, 1918, when the decision was made to separate these territories from the Austro-Hungarian Monarchy and to incorporate them into the Kingdom of Serbia, i.e. the future Yugoslav state. The aim of the paper is to synthesize and explain the processes and the events that occurred in Baranja immediately before and during the Grand National Assembly in Novi Sad until the First December Declaration when the Kingdom of Serbs, Croats and Slovenians was established. In this research, archival materials, contemporary newspapers and publications and relevant historiographic literature were used in order to analyze the historical period as accurately and comprehensively as possible.
\end{abstract}

Key words: Baranja, World War I, southern Hungary, creation of Yugoslavia, Grand National Assembly in Novi Sad 